Int. J. Dev. Biol. 57: 105-113 (2013)

doi: $10.1387 / \mathrm{ijdb} .130059 \mathrm{pd}$

\title{
A lifetime of migration
}

\author{
PETER DONOVAN ${ }^{*, 1}$ and CHRISTOPHER WYLIE ${ }^{2}$
}

\author{
${ }^{1}$ Sue and Bill Gross Stem Cell Research Center, Gross Hall, A CIRM Institute, UC Irvine, CA, USA and \\ ${ }^{2}$ Division of Developmental Biology, Cincinnati Children's Hospital Research Foundation, Cincinnati, Ohio, USA
}

\begin{abstract}
Careers in any profession can take a curious path. One small choice can seemingly change a career path and chance encounters open doors to new opportunities that take a person in new, unforeseen directions. For Chris Wylie, this has certainly been the case. This interview highlights how someone can build a successful career in science, how that career can be fulfilling and fun and at the same time, it is possible to have a family and a life outside of science. Chris has certainly had success in science, having built very successful labs at many institutions and helped found and grow world-renowned research centers. He gives great credit for his success to his longtime collaborator and wife, Janet Heasman. Although they have indeed made major contributions to their chosen fields of study, what is remarkable is the number of trainees that they have had pass through their labs. Ultimately for any scientist, the training of young scientists might be their greatest legacy and it is obvious the impact that great mentors such as J.Z. Young and Ruth Bellairs had on Chris and his decisions on how he ran his own lab. As Chris moves on to the next stage of his career, it seems likely that he will pursue it with as much vigor and passion as he pursued his love of scientific research, and have a lot of fun. I can't wait for the next interview!
\end{abstract}

KEY WORDS: primordial germ cell, embryo, Xenopus, chick, teaching, mentorship

When Massimo de Felici and Suzanna Dolci asked me to interview Chris for this issue I was excited about the prospect. Chris less so! In fact he seemed terrified by the idea. I tried to persuade Chris that younger scientists would learn from reading about his career and be interested in his experiences. For many younger people, it isn't obvious how one chooses a path and sets career goals. Some people know almost from birth that they want to be a doctor, a lawyer, or a scientist. For others the path isn't as clear. Luckily Chris was persuaded that his story would be informative and agreed to the interview. I think his story illustrates that it's possible to start off undetermined, follow the things that interest you, have a successful career and lots of fun. It's not necessary to have a master plan. Our phone interview lasted several hours simply because we laughed so much while reminiscing. During the interview, Chris' partner in crime and wife, Janet Heasman, a very successful scientist in her own right, patiently prepared dinner while supplying answers when Chris couldn't remember the details. As the conversation went on there was a lot of banging of pans in the background. I think Janet was getting hungry and wanted the conversation to be over. But, as they have so often done over their careers, Chris and Janet collaborated to get the job done and I obtained the answers to my questions.

Just like the primordial germ cells he has studied for most of his career Chris has, over his life and career, enjoyed periods of migratory behaviour. Chris was born in Carmarthen in South Wales, his mother having been evacuated from London during the war. At the age of three, he moved with his family to Kenya. His father, who was in the British army, was stationed there and Chris would spend his formative years in Kenya. At thirteen, when his father was de-mobbed from the army, Chris moved back to England with his family, began secondary school, and then attended Medical School in London. Over the next several years, he would travel to the USA but return each time to England. He moved around in England, variously establishing labs at University College, London, St. George's Hospital Medical School, London and The Gurdon Institute in Cambridge. He then had the opportunity to establish a new developmental biology center at the University of Minnesota, so he and Janet moved to the USA rather more permanently. Eventually, he moved to Cincinnati to direct the Division of Developmental Biology at the Cincinnati Children's Hospital in Ohio. It's clear from talking to him that, unlike primordial germ cells, his own

Abbreviations used in this paper: B.Sc. Bachelor of Science undergraduate degree; BSDB, British Society of Developmental Biology; CoB, Company of Biologists; JEEM, Journal of Embryology and Experimental Morphology; UCL, University College London.

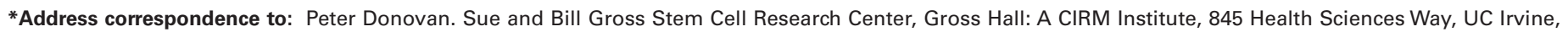
Irvine, CA 92697, USA. E-mail: pdonovan@uci.edu
}

Final, author-corrected PDF published online: 5 June 2013.

ISSN: Online 1696-3547, Print 0214-6282

(C) 2013 UBC Press

Printed in Spain 
migrations were not planned but rather fortuitous. Opportunities arose, sometimes through chance encounters, and he and Janet chose a path that offered excitement and new challenges. Like a primordial germ cell, however, Chris' behaviour seems to have been to follow the path that was most attractive and stimulating, enjoy life and all it had to offer. As you read this interview, I hope you find it as much fun to read as it was to conduct.

You spent part of your early life in East Africa. Did you have an opportunity to see the wildlife there and did that have an influence on your interest in science?

Although I never thought of it in that way, you may be right. In Africa biology is inescapable. Even on the coast, away from the big game areas of the hinterland, we were surrounded by wild life that affected our daily lives. We slept under mosquito nets to avoid malaria. We were vaccinated every five minutes to ward off various tropical infections. My early childhood pre-dated the polio vaccine, so every class had someone affected by the disease. Our garden and the surrounding neighborhood were full of snakes, including both green and black mambas, spitting cobras, kreits, and puff adders. Snake recognition was an unusual requirement, but an essential one, in daily life. A colony of iguanas lived in the bushes next to our home. We had netting on all the windows to prevent monkeys and galagos from climbing in. It is hard to ignore biology in these circumstances.

One of the most memorable experiences of Africa was taking the train from Mombasa to Nairobi. The nearest high schools to where I lived (in Mombasa) were in the capital Nairobi, and so at the beginning of each school term we would take the Mombasa/ Nairobi train, an ancient wood-burner that set off up the single track at $6 \mathrm{pm}$ and arrived in Nairobi next morning at 8am. So dawn would find us chugging through Nairobi National Park, a huge game reserve containing all kinds of wild life. One of the strangest things was to see ostriches running alongside the train in the early mornings. Why they did this I never knew, but it was an extraordinary scene. Because we lived on Mombasa island, all our family holidays were taken inland, in the highlands of Kenya and Tanzania (then Tanganyika). So I had the opportunity to visit many of the most beautiful parts of East Africa, and the big game reserves, including the iconic Ngorongoro crater. The extraordinary differences in fauna and flora made even a small boy realize the things that climate could do.

\section{What made you interested in science in the first place?}

I would like to say that I had a burning interest in science since early childhood, and spent many happy hours dissecting beetles in the kitchen. Unfortunately that would not be true; as a kid I was most interested in sport. I played football on the Mombasa European Primary School soccer team and was an ardent Spurs (Tottenham Hotspur, a North London club that plays in the English Premier League) fan. If I had any ambition at all in those days it was to play for Spurs. Later I represented my high school competitively in rugby, badminton, and swimming, and if the opportunity had arisen, would probably have taken up sport professionally (Fig. 1).

Despite my lack of interest in academic study, I became most interested in biology in high school, partly because the Zoology teacher, Bill Freeman (on the left of the picture), was also coach of the school rugby team (Fig. 2). His career advice to me was "You're a cheerful sort of chap Wylie - good bedside manner. Try medicine". I received the opposite advice from the head-master (front and center in the picture), whose response to my sudden desire to do medicine was: "The problem is Wylie that you're not very good at science. I think you would be better suited to the arts". However, I did "try medicine", based partly on Bill Freeman's advice, and partly on a dim perception of medicine being an interesting and important application of biology, mixed in a rather uncertain way with the other sciences. As a medical student in London, I had the opportunity to "intercalate" a B.Sc. into my medical training, and I chose to study in the Anatomy Dept. at University College, London (UCL), under the then department chair J.Z. Young (for

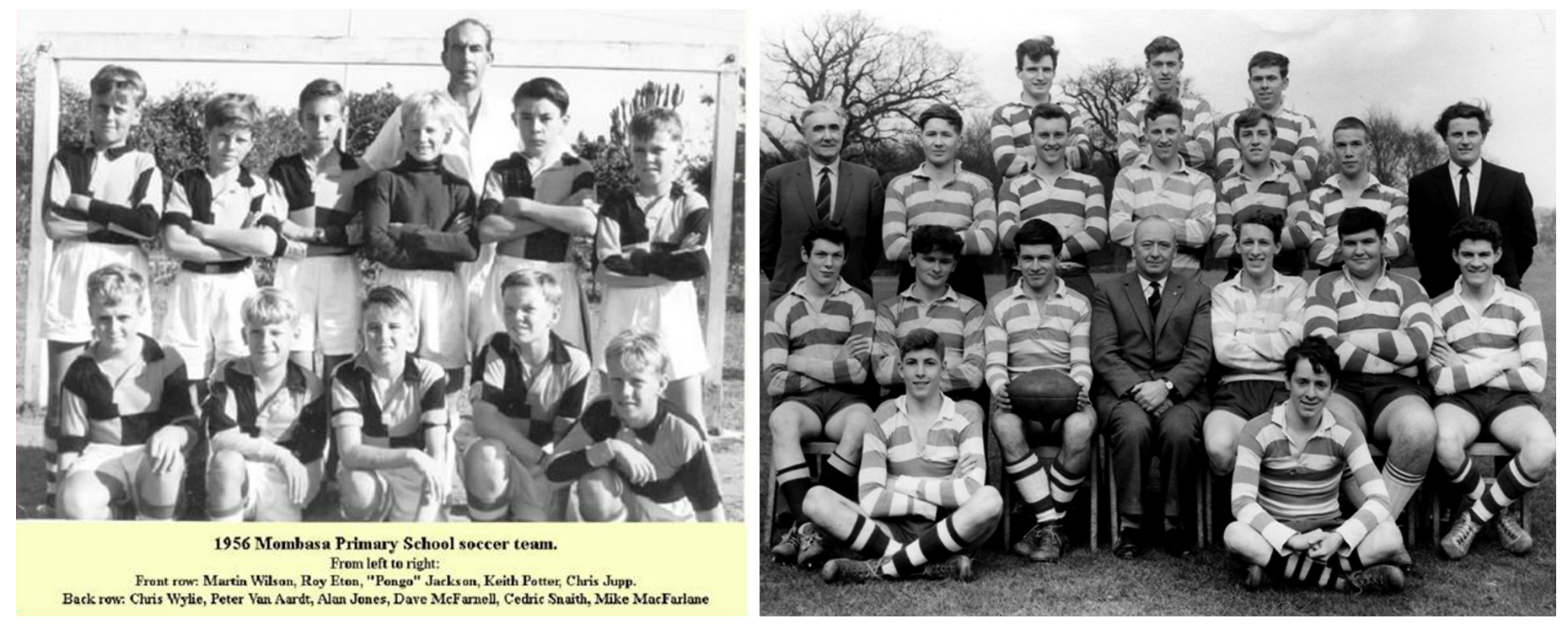

Fig. 1 (left). Chris Wylie on the Mombasa Primary School Soccer Team in 1956 (back row, left). Because of Chris' decision to pursue a career in science, Tottenham Hotspurs were to miss out on signing a talented center midfielder.

Fig. 2 (right). Chris (standing third from left in the third row) on his Grammar School Rugby team. The coach and Zoology teacher Bill Freeman (left), would encourage Chris to go to Medical School while the headmaster (center) thought Chris didn't have a future in science and should pursue the arts. 
more about the Anatomy Department at UCL of that time see the brief history written by Prof. Ruth Bellairs (Bellairs, 2010)). J. Z. was an inspirational teacher and scientist and played a major role in my scientific awakening. My epiphany (if I can use such an abused term) came when I tried to make a movie of chicken embryos developing, using an ancient mechanical movie apparatus, kept in a hot room in the department. I stayed up all night making that movie, because constant adjustments to the equipment were necessary, and I couldn't believe that structures could just appear from nowhere before my eyes. First the head process, then the neural folds, then the somites, all appearing in sequence and in amazing patterns. Of course I had seen photographs and diagrams of these things in lectures, but to see them actually appear in real time was extraordinary, and engendered a combination of awe and curiosity that has never really left me.

During the period when you were doing your B.Sc. you worked in the laboratory of Ruth Bellairs. What did you work on in Ruth's lab?

Yes, the movie that I just mentioned was taken while I was carrying out the research project that played a large part in the B.Sc. Honours course intercalated in the medical degree course. I chose to do my project in the lab of Ruth Bellairs. Ruth was a wonderful mentor. She was kind and she was patient and didn't mind that I had absolutely no previous experience of lab research (I didn't even know how to use a $\mathrm{pH}$ meter). However, I soon learned, and largely due to the fact that Ruth worked together with her students at the bench, a practice I have followed ever since, we actually published a paper from the work; "The influence of the area opaca on the development of the young chick embryo" by Bellairs, R., Bromham, DR, Wylie, CC., published in the Journal of Embryology and Experimental Morphology (Bellairs et al., 1967). Notice the author sequence, with Ruth first and me last. Changes in publishing conventions have completely reversed this over the years. In fact, later on as I went on to do a Ph.D. in Ruth's lab I would publish my work quite independently. Ruth didn't want to be on my Ph.D papers and told me: "It's your Ph.D work Chris, you publish it". In those days that practice was the norm. It isn't possible now because continued grant funding requires the Pl's name to be on every paper from the lab. It was in that period during the B.Sc course that I really fell in love with science; and for the first time in my life, I really worked hard, and gained a $1^{\text {st }}$ Class Honours B.Sc.

After doing your B.Sc you had the opportunity to do a Ph.D. rather than return immediately to Medical School. How did that come about and how did you make that choice?

Getting a $1^{\text {st }}$ meant that I was invited to do a Ph.D. in the Anatomy Department at UCL. If this had not happened I would have gone back to finish my clinical studies, and my life would have been very different. I thought for a long time about whether I really wanted to do a Ph.D and eventually decided: "Yes, actually I really do want to do this". I wasn't sure it was such a good career choice; I already knew that clinicians earned a lot more money than academics, but I decided it was what I really wanted to do.

You were offered a slot in Ruth's lab to do your Ph.D but by this time you had become interested in the emerging field of molecular biology.

Ruth offered me a PhD place in her lab but there was one issue.
I told her that what I really wanted to do was study the molecular biology of development. It seems strange these days, but this was a very small field in the mid-late 1960's. Messenger RNA had only recently been discovered, and RNA studies of embryos were in their infancy. She suggested I look around for courses in molecular biology and then come back to the lab to do a Ph.D. She then helped me identify a course in biochemistry at St. Bartholomew's Hospital and off I went there for a year. So I actually have two B.Sc. degrees! I then returned to UCL to start my Ph.D. and found myself next to Martin Evans who was just finishing up a Ph.D. on RNA isolation from early Xenopus embryos. He had been officially working under Dr. Elizabeth Deuchar but she left UCL and Martin was finishing up on his own. He and I muddled along, I working on early chick embryos and he on early Xenopus embryos. I was extremely lucky because Martin had already trouble-shot many of the early difficulties of isolating RNA from early embryos without its degradation, a major problem before the use of today's chaotropic reagents. For example, we used to spin the hectorite clay bentonite through all our solutions, because it inhibited ribonucleases. We had to build our own electrophoresis machines to run RNA gels, which resulted in several near-electrocutions, and a memorable flooding of the lab when the cooling pipe fractured. But the work was huge fun, and by the time I was ready to write up my Ph.D. I knew I wanted to continue in science if an opportunity arose. However, at this point I still intended to go back and finish my clinical studies.

\section{How did it come about that you were offered a position as a Lecturer (Assistant Professor)?}

One day when I was sitting writing up my Ph.D. the department chair J.Z. Young bowled into the little office that I shared with Martin and said: "You know we've got a lectureship opening up Chris. I wonder if you'd like it". Just like that! Those were very different times, which I sometimes fondly recall when sitting at yet another recruitment dinner. So this was decision time for me. I knew that I was expected to go back to medical school and finish up my studies, but on the other hand, I hadn't yet published my Ph.D. work, and I had also fallen in love with teaching. So I thought maybe I would take the lectureship for a couple of years, finish up the papers from my Ph.D, and enjoy teaching the medical and science students, then go back and finish my medical training. But of course this never happened.

\section{What made you decide not to go back to Medical School?}

I was just carried away by the academic life. There was always something interesting going on and during this time I became more and more certain that I wanted to be an academic. It was hard for me to imagine being paid for something I enjoyed so much. But I did think rationally about it. I would have had to do three years of clinical studies and then residency, which would have taken another year and a half, to become a card-carrying doctor. I realized that this meant four and a half years out of science, and it would have been very hard to have come back to full-time basic research after that. So it probably meant committing myself to a clinical career. I just could never take the plunge and do that. At that time clinicians worked for Britain's National Health Service and, in the London teaching hospitals, many of them had private practices on the side. There was very little time left for research, certainly not the time and facilities for the research I wanted to do, for I was really hooked on the cellular and molecular basis of development by that 
time. I found that I loved doing experiments, not just the "grand ideas" ones, but the trivial everyday things like cutting histological sections, running gels and columns, making and adapting bits of equipment, poring over results and trying to make sense of them, using each result to try to think of a new experiment. I found that discovering things was profoundly satisfying; not necessarily big and important things, just new things. I had also discovered a love of teaching. As a PhD student in the Anatomy Dept. at UCL, teaching had been a major part of each week. We were expected to run teaching labs and tutorials to medical students and B.Sc students three or four mornings each week. To my surprise, because I was quite nervous about this, I found I really enjoyed it. I liked doing the background reading. I liked the feeling of knowing so much about something that I could convey the information to others. I liked trying to make it interesting and exciting. I liked the dialog with the students. So as those initial years as a lecturer went by, it was not a difficult decision to turn permanently in the direction of academia.

After starting your own lab at UCL you then had the opportunity to work in the USA. What brought you first of all to the USA and what did you learn there?

Curiosity really. While I was a young lecturer at UCL, a mathematical biologist from Dartmouth College in the USA, Tom Roos, came over on sabbatical leave. He came to chat to me and by this time I had met Janet Heasman (who would later become my wife) and we had started working on Xenopus germ cells together (Fig. 3).

Tom became fascinated by this work and he invited me to do a sabbatical year at Dartmouth. I thought that this was a nice opportunity, and decided to go and see what it was like to teach and carry out research in the USA. Dartmouth was hardly typical of American higher education institutes, but of course I didn't know that at the time. Janet and I loved our time at Dartmouth. First, Northern New England is beautiful and we had never experienced a climate or ecosystem like it. Janet and I had to teach to earn our salaries there, so we taught an undergraduate biology class and a senior class also taken by graduate students. We had a ball! We managed to stay about a day ahead of the students. You need to realize here that we both came out of Medical School so knew nothing about real biology (which resulted in some hilarious escapades with the students as we tried to incorporate local fauna into the lab section of the course), so this was an intense learning experience for both of us. This was also the first time I realized the significance of "research grants". It is hard to imagine now, but until then, both my salary and research expenses had been paid for by the Anatomy Department at UCL. The other faculty at Dartmouth talked incessantly about grants and so I started to listen. I learned about the National Institutes of Health $(\mathrm{NIH})$ and discovered that if you got a grant you could hire people called postdocs, who would help you carry out your research. So the first thing I did upon my return to the UK was to apply for a grant. At Dartmouth, I also had an opportunity to sit on a search committee for my replacement (Dartmouth was seeking a permanent faculty member in Developmental Biology at the time). This also expanded my horizons with respect to American science, because we interviewed a number of people who were postdocs, a cadre of scientists I knew very little about. Some of the people who visited, including Joan Ruderman and Rob Grainger, I have remained friends with to this day.
After your year in Dartmouth you then returned to England.

Before going to the USA I had accepted a position as Senior Lecturer (Associate Professor) at St. George's Hospital Medical School. This was an extraordinary opportunity, for St. George's, previously a small medical school that taught only the clinical part of the medical curriculum, was opening a new preclinical school, and relocating to South London, so I would be a pioneer, and senior, faculty member, and thus able to influence the medical curriculum, and be free to plan new courses. This was exciting, and rare in the traditional world of British medical school teaching. And so when Janet and I returned from Dartmouth College we moved to South London, a major cultural change for us North London types. Janet finished her Ph.D at St. George's and never returned to Medical School at UCL. She obtained a grant from the Wellcome Trust that allowed her to finish her Ph.D. and was then hired as a lecturer at St. George's. I obtained my first ever grant from the Cancer Research Campaign and we began to build a research team.

You then had the opportunity to return to the USA. How did that come about and what did you do there?

Joan Ruderman, whom I had met at Dartmouth, visited us at St. George's and we went out to dinner together. Janet and I both taught Human Anatomy at St. George's, and Joan mentioned that they always had a hard time finding Anatomy teachers at Harvard. So not long afterwards I received a phone call from Betty Hay (then Chair of Anatomy at Harvard Medical School) asking if I would come

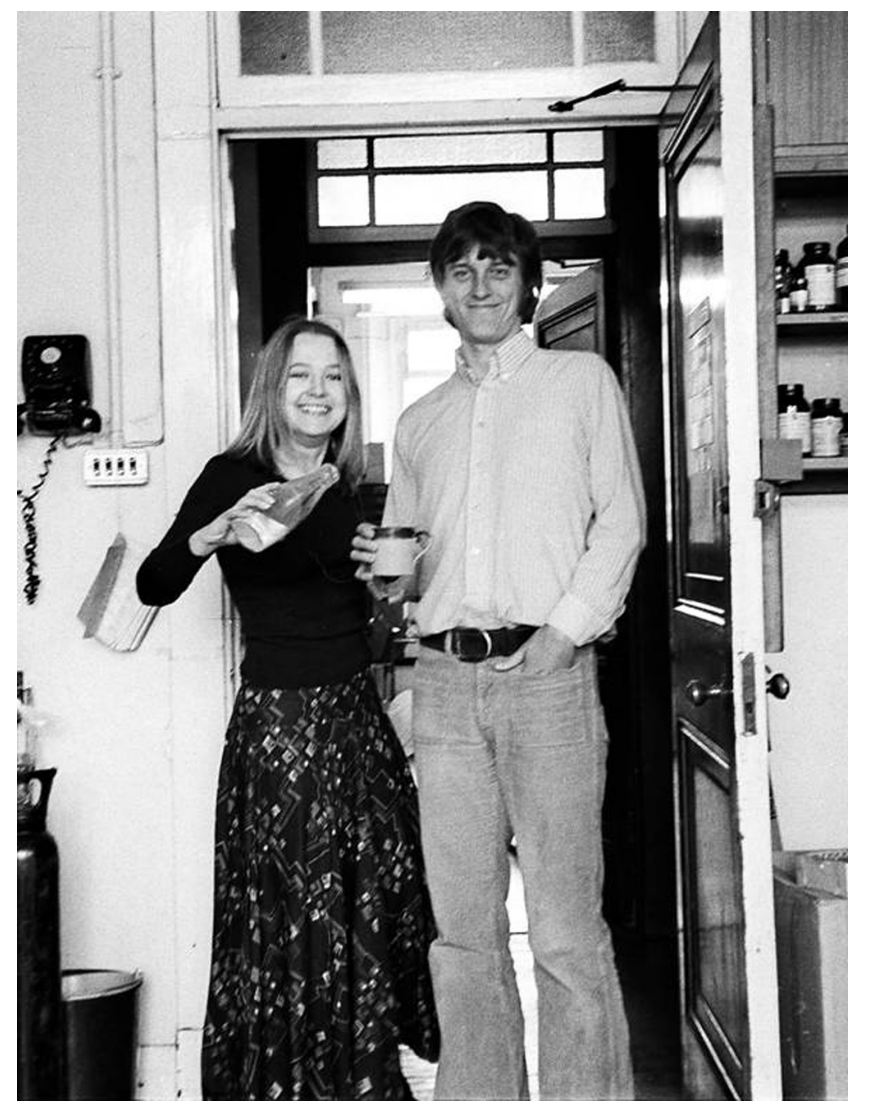

Fig. 3. Chris with his future wife Janet Heasman in the Anatomy Department at University College London in 1973. 
over and teach anatomy there for a year. So we went over for about nine months and both taught human anatomy to Harvard medical and dental students. While in Boston, we did a research project with Richard Hynes at MIT. His interest in fibronectin, and ours in the adhesive and motile behaviour of Xenopus primordial germ cells, generated a great collaboration, a lasting friendship, and our first Cell paper (Heasman et al., 1981) on the role of fibronectin in primordial germ cell migration. We then again returned to England, more sorrowfully and thoughtfully this time, for we had grown very fond of the American scientific environment, and continued to build our research team at St. George's.

What were the things you liked most about running a lab and what were the things you liked least?

Well, nothing's changed in this respect. I liked most, and still do, carrying out experiments at the bench, and sharing this experience with trainees in the lab. I liked least, and still do, all the bureaucratic necessities that accompany any kind of bio-medical research endeavor. I have noticed over the years how much scientists hate being told what to do (individuality being one of the hallmarks of a good scientist, I guess this is not surprising). This is a trait that needs to be handled carefully, particularly in interactions with the administrative aspects of research.

When you started your own lab what were the major challenges you faced?

As a starting lecturer in Anatomy at UCL, teaching and research were of equal importance. Teaching loads were large by today's medical school standards. I directed and taught, single-handed, a whole histology course. At the same time I lectured in human anatomy and embryology, co- taught a senior level course in biochemical embryology, and took B.Sc students into my lab for their honours research projects. I also took a Ph.D student. I can remember thinking to myself after my first few months that people who referred to "the still waters of the academic life" should try it for a bit. Despite the requirements to succeed at both teaching and research, and the concomitant amount of work, I found the rewards to be great, and of course London in the late 60's and early 70's was a place of enormous energy, optimism and excitement.

How do you think things have changed since then? What challenges do you see for starting young faculty now?

Faculty positions have diverged a bit since my early days. For a predominantly teaching position one needs to have already demonstrated excellence in teaching, and for a position in research, to already have a stellar track record in research publication and the ability to attract grants. There are fewer of the "all-round" positions that were the norm when I was starting out. For young faculty in university teaching departments, biology departments for example, teaching is a huge (and oft-underestimated) challenge. It is noteasy to be a good teacher at university level. For someone entering a more research-focused position, in a medical school or research institute, the challenges are very different. Discussions with young faculty identify three major worries: getting good mentorship, getting good lab personnel, and getting grants. These are of course, highly interconnected. I think that "pathway" documents can help. When I started at Cincinnati Children's Hospital, I wrote a document called "Road to tenure" for all the young faculty being recruited, which focused on these issues. From my own experience of young faculty starting out now, I think that their greatest fear is failure; not surprising in the current highly competitive climate for publications and grants. It has become an important role for academic leaders to try to allay these fears, and not let them affect performance, behavior, and attitudes, of young faculty.

For much of your scientific career you studied primordial germ cells first in frogs then in mice. How did you become interested in those cells?

Funnily enough, it was not germ cells themselves that interested us (I say "us" because Janet Heasman and I started working together at this time), it was the germ plasm that was known to initiate germ cell formation in Xenopus. I had read of Dennis Smith's pioneering work in which he irradiated the vegetal poles of Rana eggs, and caused sterility which could be rescued by injection of vegetal, but not animal, cytoplasm (Smith, 1966). I had the daft idea that we might be able to fractionate the vegetal cytoplasm to find the active factor. To assay the results of our efforts, we needed to count the germ cells that formed in the embryo. So we studied them at different stages in histological sections, and tried to figure out ways to quantitate them. We discovered, to our surprise, that they were so large during the time they colonise the genital ridges that we could dissociate dissected early larvae and isolate the germ cells under a dissecting microscope and count them physically. These huge cells were clearly motile, and this led to our study of their migratory properties, and the control of the migration process. We never did successfully fractionate the germ plasm, although our attempts at germ plasm fractionation did lead us in an unexpected direction. We found to our surprise that the germ plasm islands were hard and jelly-like, rather like the lumps in tapioca. Thinking about how this might be so led us to our later studies of the cytoskeleton of the oocytes and early embryos.

Germ cells have a unique place in developmental biology. It's an important field in different experimental systems, flies, worms, frogs, fish and mice. Why do you think they fascinate so many people?

Germ cells simply are fascinating. They occupy a central position in almost all aspects of our lives. We eat them. We inhale them (and they give us allergies). We walk on them when we go hiking, swim amongst them in the sea. They are the basis of crop and livestock management, of species conservation, and of our own reproduction. They have the property of pluripotency, which is at the basis of all stem cell and regeneration studies and their applications. They are the inadvertant targets of environmental agents intended to help in crop and animal management. Their biology is also fascinating. They run through the entire gamut of cellular and molecular activities during their long differentiation, which makes them models for people working on most aspects of cell biology. They just are fascinating cells.

In addition to your work on primordial germ cell migration you have also worked on development in the early Xenopus embryo. How did you get interested in that area of developmental biology and what attracts you about that work?

Xenopus is a really attractive model system to work on. Janet and I started to work on the timing of lineage commitment because early Xenopus embryos have a fate map. Since the normal fate of each cell is known, the effects of experimental manipulation can 
be assayed. The cells of the early embryo are also large and easy to manipulate. We were able to isolate individual cells from different regions of the embryo, and transplant them into host embryos under the dissecting microscope using hand-held Pasteur pipettes with the tips drawn-out over a Bunsen burner. The fact that early development is controlled by maternal mRNAs allowed the opportunity to identify individual mRNAs in the oocyte and target them using antisense constructs. This has dramatically enhanced our understanding of early vertebrate development. The ability to dissect out specific regions of the embryo and assay their developmental capacity in isolation, or when combined with other regions of the embryo, is an extremely powerful method of analysis of gene function in development. The cells of the early embryo are extremely large, enabling the visualization of cytoskeletal networks at quite low magnifications. Also, the effects of manipulation of cytoskeletal components can be directly assayed in vivo, in clones of cells, by the effects on morphogenetic movements. Xenopus is an extremely attractive in vivo model for cytoskeletal studies for this reason.

More recently you have begun to work on other things such as ageing of the intervertebral disc. A distinguished scientist recently remarked to me that as scientists become older they all start to become interested in problems of ageing. Is that the reason or are there other things that drew you to that field? And how did you become interested in developing a developmentally-based tissue engineering approach to improve tendon repair?

I'm going to take these two questions together. One advantage of building a center of developmental biology in a Children's Hospital is the opportunity it offers to do projects that one would not normally think of. Both of these projects started from casual conversations over coffee with respectively, an orthopedic surgeon and a biomedical engineer. In the first case, a discussion of the treatment of spinal deformities and injuries quickly revealed how little was known about the control of spine growth during childhood. So I decided we should do some basic work to identify signaling pathways that control the growth and differentiation of intervertebral discs. The results have been extremely interesting, and have revealed that the nucleus pulposus, the semi-liquid center of each disc, is not simply a passive shock absorber between each vertebra, but contains cells derived from the embryonic notochord that act as signaling centers controlling growth and differentiation of the discs. This is very satisfying, not only from a developmental standpoint, since it explains how the simultaneous growth of all the discs can be coordinated, but also from a clinical standpoint, since it may yield treatments for disc degeneration and injury in the future - too late for me I'm afraid, in answer to your question! In the case of the tendon project, the conversation turned on how important it is to try to engineer tendon in culture as replacements for injured tendons, which rarely heal properly. Once again, we quickly realized that almost nothing was known of the normal signals that initiate or control the differentiation and proliferation of tendon cells, and so we started a study to uncover these, using the mouse as a model, with a view to using the results to bio-engineer tendon tissue in culture. It is important to realize that developmental biology research has developed and/or refined many technologies over the years, so that modern developmental biologists all have a widely applicable toolbox of techniques that can be applied to many clinically relevant problems. I believe that it will be increasingly important in the future to locate developmental biologists immediately adjacent to clinicians, and other applied scientists (anthropologists, ecologists, crop scientists, and so on), to expose them to these translational opportunities. This is an era where cross-discipline research will be increasingly important, and developmental biologists should embrace these opportunities.

While at St. George's Hospital in London you became the founding Editor of the journal, Development which has become one of the premier journals in the field of developmental biology. That was an enormous undertaking. What on earth were you thinking?

Mercifully, I am not especially blessed with foresight! It was a progression of things. I didn't wake up one morning wanting to be a journal editor. I was the Publications Secretary of the British Society of Developmental Biology, and it was my job to identify ideas, and organisers, for the society's symposia. These were published first by Cambridge University Press, and then by the Company of Biologists ( $\mathrm{COB}$-the publishers and owners of JEEM, the Journal of Embryology and Experimental Morphology). These symposia became very good, better in many cases than the parent journal, and it occurred to me that the huge new data set emerging from the combination of genetic, molecular, physiological, and experimental embryology approaches to development was not being captured by any of the mainstream journals. I proposed, therefore, to the BSDB that we start a new journal. I had no thoughts of editing it. After much discussion with different publishers, including the CoB, I was asked if I would like to take over the editorship of JEEM. My reply was no, but that I would consider editing a journal with a broader outlook, more modern style, free use of color, A4 page size, travel scholarships for young scientists from the income, free reprints, and a number of other things. I wanted to break what I saw as an exploitive situation in which scientists had to pay to publish their work in premier journals (through page charges to the publishers) and then pay again to read it. To my surprise, the CoB agreed to re-launch JEEM as Development, and I found myself the editor of a journal (Wylie, 2013).

You were one of the founding members of the Gurdon Institute in Cambridge. That must have been an exciting endeavor to found a new institute. What attracted you to that challenge?

The challenge itself. It was a unique opportunity to start a major center of developmental biology, to work with people I highly respected, and to recruit the very best young developmental biologists, many of whom could be attracted back from Europe and the USA by this new institute, and the opportunities it offered.

In being involved in founding a new institute what things did you and the other principals involved decide would be the hallmarks? Were there things that you thought you might try that were different or new?

Very interesting question, because it illustrates the large gap between planning and reality. The institute, as originally conceived, would be home to five senior investigators (Michael Akam, John Gurdon, Janet Heasman, Ron Laskey, and myself) and six junior investigators. The senior investigators would have their tenure homes in university departments, but work in the institute for as long as they could maintain their grants from the Wellcome Trust or the Cancer Research Campaign. These were reviewed for renewal 
every five years. The junior investigators would have five-year contracts, renewable for a further period of time if necessary for them to find permanent positions. The idea of this was to create a "research hotel" or incubator for the best young developmental biologists, who would then re-populate British universities whose research had been badly affected by the Thatcher regime. In actuality, the reverse happened. All but one of the senior investigators has moved on, and all but one of the original junior investigators are still there (indeed one is the Director). All this goes to show that one needs to be flexible in planning a new institute!

In 1994 you moved back to the USA, to become director of the Developmental Biology Center at the University of Minnesota School of Medicine and eventually moved to Cincinnati to direct the Developmental Biology Division at Cincinnati Children's Hospital. What attracted you back to the USA?

I had grown to love the rich and varied culture of the USA. For eight years Janet and I taught the Embryology course at the Marine Biological Laboratory (MBL) at Woods Hole. We would bring the kids with us, and teach this intensive course to graduate students, postdocs, and faculty members, while the children had the time of their lives with the children of other faculty members and summer researchers at the MBL. Living amongst researchers and their families each summer, I came to realize how much I enjoyed the scale and scope of American science, the astonishingly beautiful and varied scenery, and the lifestyle of its researchers. So it wasn't too difficult a decision when a challenging opportunity arose at the University of Minnesota to establish a new developmental biology center.

You have had many people train in your lab. What has been your philosophy of how to train scientists and what do you see as the rewards of training young people?

I have found the most important thing is to be adaptable. Some trainees require rather little mentorship. Some think they do but really don't, and some think they don't but really do. Careful thought and observation are required before settling on a regime of mentorship for each individual. I also think it is essential to work alongside trainees as much as time permits (sometimes regrettably not very long). I think that encouragement is the best incentive, coupled to honesty with respect to progress made and requirements for improvement. I have found the rewards of training young scientists to be immense. They enhance the capabilities of the lab. They bring new energy and insight, as well as maintaining a steady stream of new technologies. Perhaps the greatest reward is seeing their success (Fig. 4).

What do you see as the new horizons in biology - maybe specifically in the areas that you are interested in?

My environment obviously colors my view here. I have spent twelve years building a developmental biology center that has strong links with the clinical divisions at Cincinnati Children's Hospital. I have made a large number of joint appointments with clinical divisions, so that both sides of the organogenesis process, basic science and clinical, are represented in the division. There is still much to do, and novel technologies will help. Exome sequencing of children with congenital disorders will reveal novel allelic series, whose functional implications will be testable with increasing facility in model organism and stem cell models, leading to more rapid screening for potential small molecule agonists and antagonists that may be useful for early prevention in the future. I also think there will be increasing influence of basic developmental biology in other applied fields such as crop management, environmental biology, conservation biology, and human and animal reproduction. Links between developmental biology and medicine are stealing the headlines at the moment, but I think that there will be major applications of development to managing many aspects of the world about us in the future. In our field, I think that microscopy at near-molecular levels will dramatically affect our ability to "see" protein:protein interactions, rather than to infer them from pull-downs and structural analysis. This will add a spatial level of analysis of gene mutations which will lead to novel approaches to diagnosis and treatment of congenital disorders, as well as analysis of normal function.

During my time in the lab you had many visitors: Anne McLaren, Norio Nakatsuji, Massimo de Felici, Keith Dixon, Jim "I'II light the fireworks" Smith, Chris Ford amongst others. That seemed to be a regular feature of the lab. Is that something you planned or that just evolved? How important are those types of visits both for yourself and Janet as principal investigators and for the people in your lab?

These things just happened. We used to meet people at conferences, have a few drinks and discuss experiments. Next thing we knew they were in the lab working with us. I think that kind of spontaneous sharing of ideas, coupled with the willingness to test them out together at the bench is the life blood of research, and I am sad that Principal Investigators themselves don't seem to do this any more. We have been very fortunate in having this continue throughout our careers. Many of our papers are collabora-

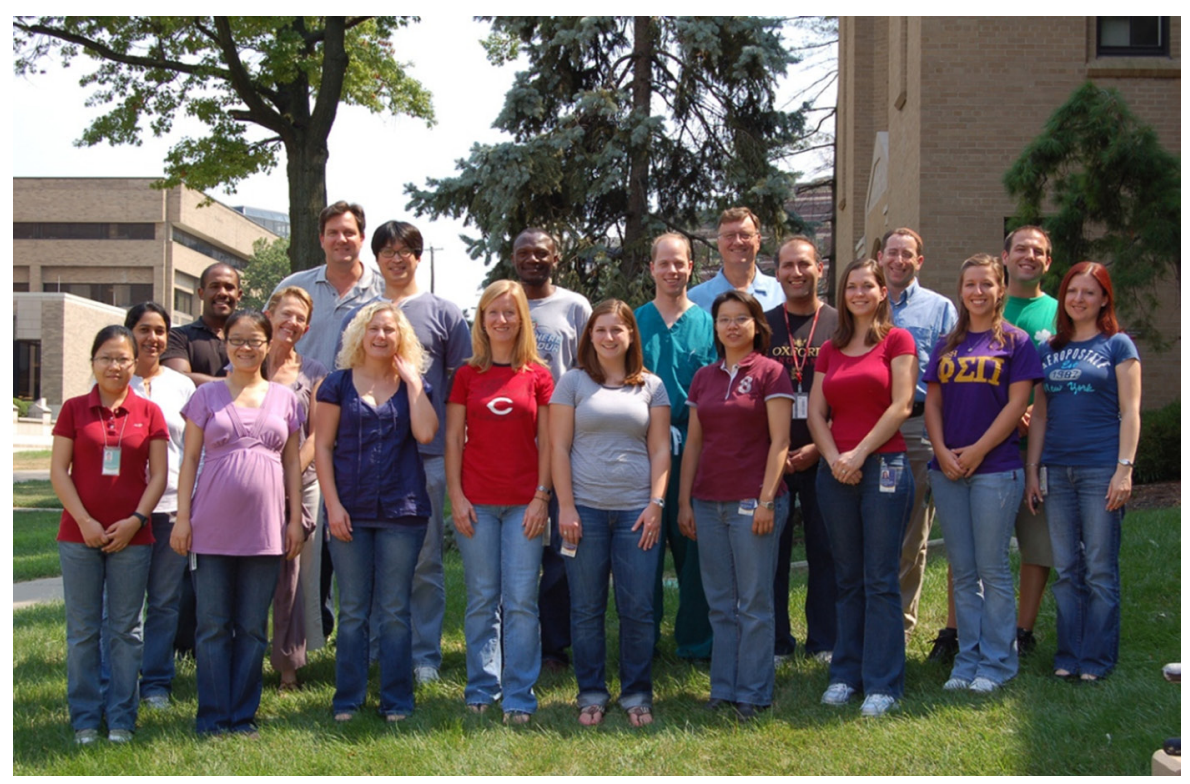

Fig. 4. The Wylie/Heasman lab in Cincinnati in 2011. 
tive, and have involved us working together at the bench with our collaborators. These collaborations cross fertilised our laboratory with those of our collaborators, with respect to both new ideas and new technologies. Without this our progress would have been much slower. Now you mention it, these collaborative experiments, often initiated at scientific meetings (Fig. 5) have been some of the highlights of my career.

What do you see as the major challenges to scientific research at the moment and in the next decade?

Money, fashion and public attitudes. Money because research is not possible without it. The recent decline in federal grant budgets in the USA is causing a contraction in the numbers of trainees and young faculty members that will take many years to recover from. We saw a similar reduction in public funds during the Thatcher years in Britain, which caused the concentration of limited resources to a very small number of centers. This would be a disaster in the USA. If research funding becomes concentrated into a small number of centers it will increase the already dangerous polarization of attitudes to research in some parts of the country. To avoid this, it is important to maintain centers of excellence in research and science education in all states. Fashion because I am a great believer in "Investigator-initiated research" and an opponent of "directed research" programs by grant-awarding agencies. Most of the major advances in our field were made in a blue skies fashion by individual investigators with truly creative and original ideas, and not in response to RFA's from the $\mathrm{NIH}$, or similar government-directed research programs. Public attitudes because they can still be dangerous, even in these more enlightened times. Even in my own state, which is well-educated, industrialized, and modern in most ways, there are still determined attempts in the state legislature to criminalize stem cell research.

In the longer term, I think the greatest threat to research lies in the lack of an early science education. Science plays such a fundamental role in our lives that its basic principles should be taught early, and well. And yet, because it is perceived as "difficult", science tends to be kept until later, by which time the natural curiosity of the young child has been replaced by the just-as-natural diffidence of the teenager, and learning science really does become difficult.

In one of your other answers you allude to the fact that you liked trying to communicate science well to an audience, whether it be medical students or fellow scientists. I learned a lot from you about communicating science. Did you ever have to communicate science to a lay audience and how important do you think it is for scientists to be able to explain their work to the public?

This is one of the most important, and poorly-executed, components of science. It is essential, for the future of public funding of science, that the public, or at least their representatives in government, fully understand what is being done, why, and realistically how (and this is the bit we often get wrong) it will benefit medicine, or industry, or just increase our knowledge. I have had a lot of fun trying to communicate science to non-scientists. I remember being invited to discuss "something scientific"(!) to my oldest son's primary school class. I elected to take a human skull with me, and spent some time describing to the class of six-year olds where the brain went, how the skull was made, where all the holes were for nerves and blood vessels to get in and out, how the jaw worked, and so on. At the end, I asked the class where they would least like their skull to be hit. The first answer was: "in the playground sir". However, the second person, very satisfyingly, got it right. I enjoyed, in a nervous sort of way, presenting regularly on Science Now, a radio program that went out on BBC World Service. I was never very good at this, but it resulted in invitations to give talks to lay audiences sometimes. I remember giving a talk at the Merton Public Library (a Southwestern suburb of London), to the Merton Scientific Society. The lecture was given at $8 \mathrm{pm}$, and the audience consisted approximately equally of school-children and sleeping vagrants. In more recent years, I have found that giving

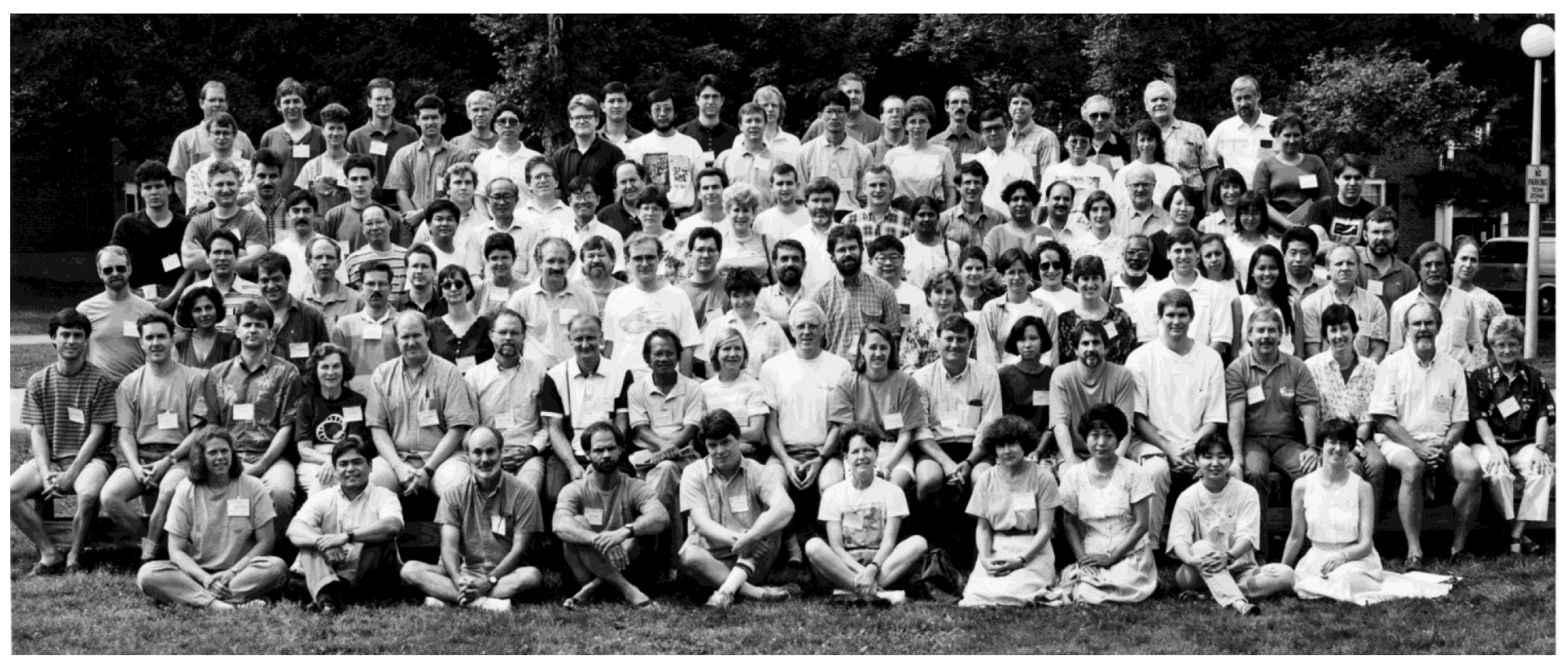

Fig. 5. Chris (eighth from the right in the second row) attending the Gordon Conference on Mammalian Embryogenesis and Gametogenesis in 1994 at Colby Sawyer College, New London, New Hampshire, USA. It was at meetings such as these that many friendships and collaborations were made. Photo kindly provided by Grant MacGregor. 

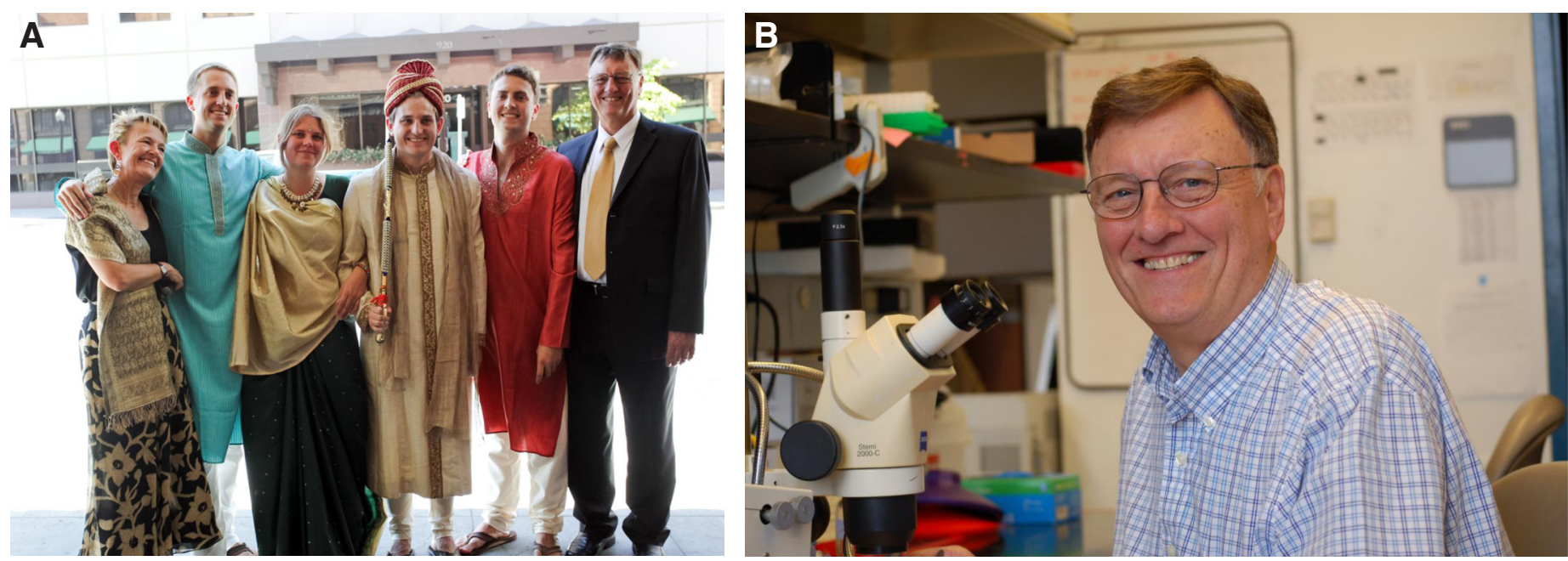

Fig. 6. Germ cell migration - Science, family and fun. (A) Chris and Janet and their kids (left to right), Michael, Sara, Matt and Jake gathered with Matt for his wedding. City ordinances required Matt's sword to be tied into its scabbard!!. (B) Chris at the lab bench in 2010 still having fun.

regular talks to our Board of Trustees has been incredibly helpful in maintaining their support for basic research. For those of us who use public money for our research, it is a duty to repay that debt by conveying to our benefactors both the resulting increased scientific knowledge, and a better understanding of what science is, and how it is carried out.

You and Janet raised four (it seems like many more) kids while still running a lab, having many research projects and at one point running a journal. You seemed to do it effortlessly. How did you manage that and do you have any advice for balancing a career and a family life?

We did indeed raise four children (Fig. 6A). It really isn't that difficult, as long as both partners are willing to adapt. While the kids were small we worked shifts, and tended to focus on one project at a time. Efficiency becomes essential. Breakfast in our home was like a precision military exercise. My advice is: if you want children, have them, and make other aspects of your life work around them. Waiting until "the right time" is inadvisable because in my experience the right time is poorly-defined, and continues to recede into the future as conditions are added (or not met). One sad aspect of science is the way in which increased regulation has made the life of a scientist more of a mystery to their young children, because they are not allowed in research labs. When our kids were small they could come into our lab, and learn in a fun way about things that are mundane to us, but exciting and mysterious to kids. They could all pipette saline accurately from tube to tube, measure volume and weight, and had a basic understanding of what a microscope was, almost before they started school. Voyages to the frog room were viewed with great excitement, and resulted in an early understanding of animal research and animal care. Of course laboratories are dangerous places, and unsupervised behavior by young children can have disastrous consequences. I remember teaching our youngest son Jake how to pick something up with forceps. Unfortunately, he chose to pick up a piece of dry ice and place it into a plastic screw-top tube, which he then screwed up and left on the bench!

\section{Over the years who were the people that had a major influence} on your career or your science?

I would select four, in temporal order. First, my zoology teacher, Bill Freeman, at high school in South London. He made both learning and sport fun. Second is J.Z. Young; a major role model in the value of basic research to medicine, and without whose inspirational teaching I would certainly not have taken either a B.Sc. or a Ph.D. during my medical course. Third is Ruth Bellairs. Ruth was a wonderful mentor. She also made me realize that doing science could be fun. Her lab was a happy place that I have always tried to emulate. She also had great insight into human relationships. I remember her saying once, when I remarked on how kindly she treated the mistakes of her graduate students: "never be rude to your trainees Chris, they may be your department chair some day". Astonishingly, this actually happened. Claudio Stern, who did his postdoctoral fellowship in Ruth's lab, ended up as her department chair many years later. Fourth, and most important, is Janet Heasman, my partner in life as well as in science. Janet brought a combination of truly incisive, original thinking, and a degree of commitment and hard work that I had never before encountered, and still marvel at. We have shared the highs and lows of the research life together, and all our successes have been shared ones. I feel very lucky (Fig. 6B).

\section{References}

BELLAIRS R (2010) UCL Anatomy Department - 60 Years Ago. http://wwwuclacuk/ $\mathrm{cdb} /$ about/history/bellairs.

BELLAIRS R, BROMHAM DR, WYLIE CC (1967) The influence of the area opaca on the development of the young chick embryo. J Embryol Exp Morphol 17: 195-212.

HEASMAN J, HYNES RO, SWAN AP, THOMAS V, WYLIE CC (1981) Primordial germ cells of Xenopus embryos: the role of fibronectin in their adhesion during migration. Cell 27: 437-447.

SMITH LD (1966) The role of a "germinal plasm" in the formation of primordial germ cells in Rana pipiens. Dev Biol 14: 330-347.

WYLIE C (2012) In the beginning. Development 139: 1889-1890. 


\section{Further Related Reading, published previously in the Int. J. Dev. Biol.}

The migration and loss of human primordial germ stem cells from the hind gut epithelium towards the gonadal ridge Linn Salto Mamsen, Christian Beltoft Brøchner, Anne Grete Byskov and Kjeld Møllgard

Int. J. Dev. Biol. (2012) 56: 771-778

Gene expression profiling identifies eleven DNA repair genes down-regulated during mouse neural crest cell migration Domenico Albino, Antonella Brizzolara, Stefano Moretti, Carla Falugi, Valentina Mirisola, Paola Scaruffi, Michele Di Candia, Mauro Truini, Simona Coco, Stefano Bonassi and Gian Paolo Tonini Int. J. Dev. Biol. (2011) 55: 65-72

Matrix metalloproteinase-2 is involved in the migration and network formation of enteric neural crest-derived cells Richard B. Anderson

Int. J. Dev. Biol. (2010) 54: 63-69

Inter-species transplantation and migration of primordial germ cells in cyprinid fish Taiju Saito, Rie Goto-Kazeto, Takafumi Fujimoto, Yutaka Kawakami, Katsutoshi Arai and Etsuro Yamaha Int. J. Dev. Biol. (2010) 54: 1481-1486

Migration of neural crest-derived enteric nervous system precursor cells to and within the gastrointestinal tract

Alan J. Burns

Int. J. Dev. Biol. (2005) 49: 143-150

Regulation of cell adhesion and migration in lens development Peggy S. Zelenka

Int. J. Dev. Biol. (2004) 48: 857-865

Primordial germ cell migration

Kathleen Molyneaux and Christopher Wylie

Int. J. Dev. Biol. (2004) 48: 537-543

The migration and differentiation of a chemist entangled in developmental and cancer biology. An interview with Jean-Paul Thiery.

Fred T. Bosman

Int. J. Dev. Biol. (2004) 48: 529-535

From here to there; a life based on migration. An interview with Isaiah J. Fidler Ian R. Hart

Int. J. Dev. Biol. (2004) 48: 457-462

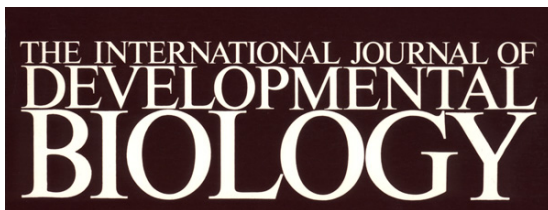

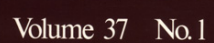

Volume 37 No.1

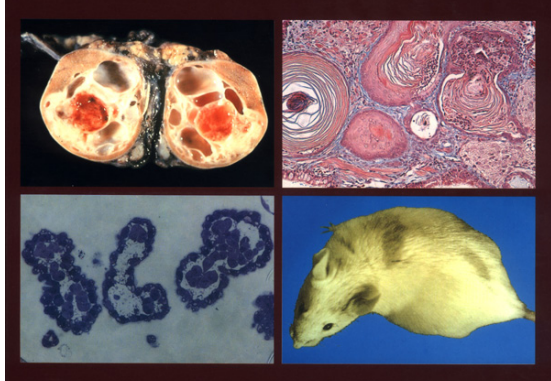

Developmental Aspects of Neoplasia
5 yr ISI Impact Factor $(2011)=2.959$

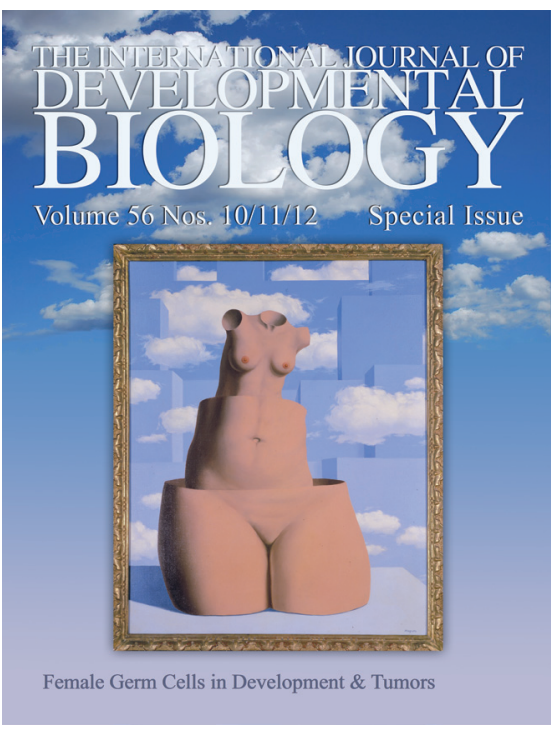

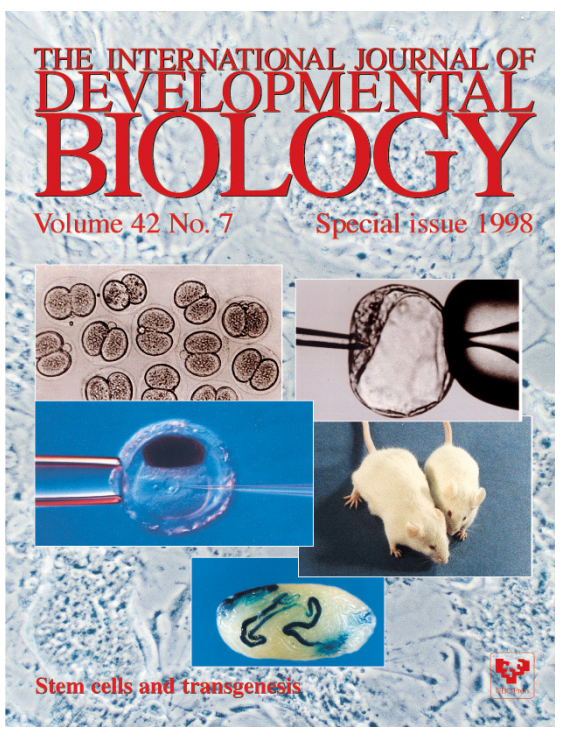

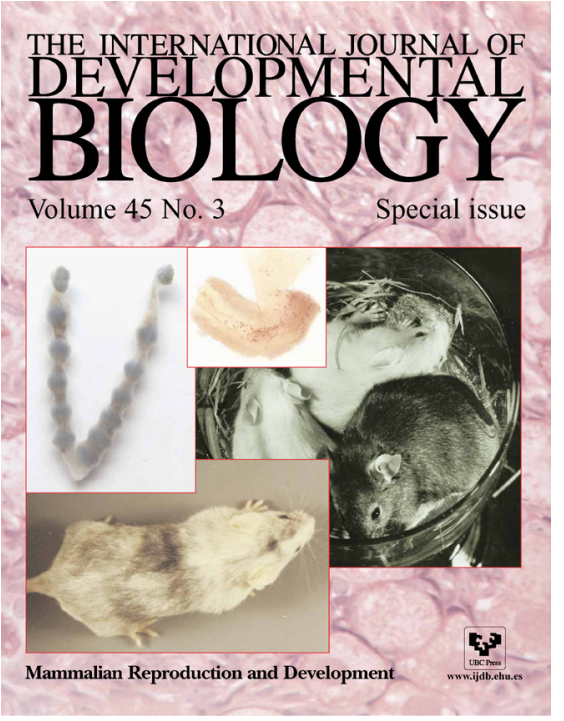

